\title{
Stakeholders and Quality Assurance in Higher Education
}

\author{
Liudvika Leisyte \\ Don F. Westerheijden \\ Elisabeth Epping \\ Marike Faber \\ Egbert de Weert
}

Paper for

$2^{\text {th }}$ Annual CHER Conference

Lausanne (CH), 2013-09-09/11

Correspondence to: d.f.westerheijden@utwente.nl 



\section{Stakeholders and Quality Assurance in Higher Education}

\section{Introduction}

The various changes in post-bureaucratic organizing, which is moving towards network approaches, coupled with the managerial agenda of corporate governance, have redefined the roles of various internal and external stakeholders in the governance of higher education institutions (Leisyte and Dee, 2012). It has been argued that university governance has been shifting from the collegial mode towards a corporatist mode (Exworthy \& Halford, 1999; Gumport, 2000; Winter, 2009). In the post-new public management discourse (Deem, 1998) the shared stakeholder (network) governance has been increasingly gaining ground as a form which embraces the key values of democracy prevalent for academia on the one hand, while incorporating the increasing notion of building trust in society-including and strengthening the role of stakeholders: students, alumni, industry and community representatives, alongside the managers, administrators and academics who have traditionally been involved in university governance (Jongbloed, Enders \& Salerno, 2008; Neave, 2002). The purpose of this chapter is thus to explore the changing role of stakeholders and the changing governance of university as a result of this, using the case of quality assurance. Specifically, we study how the implementation of the European Standards and Guidelines for Quality Assurance in the European Higher Education Area mediated by national contexts shape the notion of stakeholders in quality assurance at the institutional and programme levels.

The chapter is organized as follows. First we introduce the notion of a stakeholder and explore how it has been defined in the management and higher education studies literature and in the European Standards and Guidelines. Here we largely draw on stakeholder theory. Further, we present the methodology of the study followed by the exploration of the role of two types of stakeholders: students and employers. We conclude with a discussion on the role of stakeholders as found in the case studies, compared with the roles defined in the ESG. We close the discussion with a reflection on how the particular roles we found relate to the governance models of the particular countries we have studied in this chapter.

\section{Conceptual Underpinnings: Stakes and Holders}

Stakeholder theory has been applied to investigate the role of stakeholders in higher education (Amaral \& Magalhaes, 2002; Jongbloed et al., 2008; McDowell \& Sambell, 1999). According to Freeman (1984), stakeholders are defined as "any group or individual who is affected by or can 
affect the achievement of an organization's objectives" (Freeman, 1984, p. 46). Further, Freeman (1984) also defines stakeholder theory as "The Principle of Who or What Really Counts".

The term "stake" can be simply described as a share, interest or investment that a certain party attributes to an entity (Freeman, 1984). Proceeding from that basic notion, the main theoretical framework regarding stakeholder identification is contained in Mitchel et al. (1997), who rank stakeholders according to their salience and influence potential (Logermann, 2013). Their typology aimed at explaining what makes managers prioritise certain stakeholder relationships. It employs three criteria to identify the importance of stakeholder groups and interests which create a stakeholder hierarchy. The ordering builds on stakeholder salience, defined tautologically as "[t]he degree to which managers give priority to competing stakeholder claims" (Mitchel et al., 1997, p. 868). In order to investigate which stakeholders are most salient, meaning that their interests enjoy highest priority, the authors used the three criteria of power, legitimacy and urgency. A party has power in a relationship "to the extent that it can gain access to coercive, utilitarian or normative means" (Mitchel et al., 1997, p. 865) to impose its will. Legitimacy is described as "socially accepted and expected behaviour" (Mitchel et al., 1997, p. 866), which is establishing an actor's authority. Urgency, which adds the dynamic component, is defined as "the degree to which a stakeholder claims call for immediate attention" (Mitchel et al., 1997, p. 867). However, if we take a more broadly social perspective to define power, saliency and urgency, assessing stakeholder characteristics independent of the managerial point of view, the Mitchell et al. typology may well be used to characterize stakeholders in higher education.

In the current study the power of a stakeholder category could be veto power in committees associated with educational quality, it could be high status in society or business having utilitarian or normative means. In terms of having a say in programme development, a powerful stakeholder is not only present in programme committees, but has a strong say in programme development and influences changes made. The legitimacy of a stakeholder category can be understood as widely-shared expectations to be represented in various governance bodies or programme committees. Finally, urgency of a stakeholder means his presence and participation in meetings, putting forward proposals and comments and following up on action results, such as programme improvements. High urgency exists if a stakeholder has the possibility to participate in internal quality assurance procedures at any time, constantly checks the progress and maintains specific point on agenda for as long as the result is achieved. The salience of stakeholders is then the addition of all three criteria. At the lowest rung of the stakeholder salience alignment ranges the latent stakeholders; stakeholders in this class possess only one of the three attributes. From a management perspective, as the salience of these stakeholders is rather low, managers may not do anything to fulfil latent stakeholders' interests or even completely ignore them. The second category are moderately salient or expectant stakeholders, who exhibit two attributes and thus enjoy a higher degree of salience and draw the attention of the managers. The highest category of the Mitchel et al. typology is the definitive stakeholder, who possesses the entire set of attributes and will be highly salient to managers, meaning that ultimate priority will be given to their interests. 
Overall, it should be considered that Mitchel et al.'s (1997) concepts are not exclusive; any stakeholder at the lower levels may rise to become a definitive stakeholder by acquiring more attributes. Thus, it also depends on stakeholders' strategic actions if and to what degree their interests will be taken into consideration (Mitchel et al., 1997).

In this project we understand stakeholders as those actors who have a 'stake' (following Brenner, 1992), that is, those that may influence the university's behaviour, direction, process or outcomes. In the case of the IBAR project the 'stake' means the ability of a particular actor/group to influence the university's definition of quality of teaching and learning and internal quality assurance processes. Although Mitchel et al. 1997 identify a broad range of stakeholders - in the case of higher education these could include academics themselves, students, parents, administrators, managers, alumni, employers, media, community representatives - this chapter will focus on two types of stakeholders: students and employers, as the two groups which explicitly have been emphasized in the ESG.

\section{Methodology}

The research design, as in the IBAR project overall, consists of comparative case studies. In seven countries, four institutions each, for a total of 28 higher education institutions have been studied. Since quality assurance is very context specific, four countries have been chosen from the transition countries (Latvia, the Czech Republic, Slovakia and Poland) and Western European countries with varying higher education governance models (Portugal, the Netherlands and the UK). Institutions were selected to reflect the variety in binary systems (research universities and universities of applied science), small and big, comprehensive and specialized. At national level, we identified actors responsible for quality assurance in higher education such as quality assurance agencies, and we studied legislative frameworks pertinent to quality of higher education. Documentary evidence has been complemented with interviews if necessary. The institutional case studies have been carried through semi-structured interviews with a wide range of actors: teachers, policy officers, managers, students, and employers. Coordinated interview guidelines have been developed across all seven countries, with common research questions. The focus of study was implementation of the ESG, while the focus for this chapter was exploration of the role of stakeholders in internal quality assurance. Interviews have been carried out in the local language and translated for analytical purposes as used in the national reports. This chapter is based on the evidence gathered from the national reports.

\section{Stakeholders in ESG and in Higher Education Studies}

Students as stakeholders are supposed to be involved in evaluation of courses and to participate in internal quality assurance via decision-making and quality management processes at higher education institutions as equal partners. According to the ESG the role of employers is more ambiguous. The ESG emphasize the role of stakeholders in internal quality assurance in terms of representation as well as participation in study programme development. Standard 1.1 notes that internal quality assurance 'should also include a role for 
students and other stakeholders'. Further, stakeholders are mentioned in ESG 1.2, which states that periodic reviews of programmes and awards should include external panel members, feedback from employers, labour market representatives and other relevant organizations. Following the typology of Mitchell, 1997, according to the ESG, students and employers are definitive stakeholders who have power, urgency and legitimacy to act.

The emphasis on stakeholders in the ESG is commensurate with changing higher education governance towards more accountability and relevance to society. In turning from collegial governance to managerial and, some argue, stakeholder and network governance, the role of the internal and external stakeholders has increased. Students have gained a bigger 'stake' through the introduction of (high) tuition fees. Although student unions may not like the term, students started to be treated-and behave! - as customers.

The recognition of students as stakeholders first appeared in the literature in 1975, ten years before tuition fees were charged in the UK (Douglas et al. 1993). According to Jongbloed et al. (2008) today higher education institutions must respond to a number of communities and groups, with students being the most important stakeholder group. Similarly, McDowell \& Sambell (1999) and Hill (1995) argue that students should be considered valuable stakeholders, especially related to internal quality assessment. Furthermore, as students are costumers, they provide essential feedback on teaching. They are increasingly regarded as partners who judge to what extent their personal aspirations are fulfilled (Jongbloed et al., 2008). Consequently, due to the growing importance of stakeholders, universities are expected to engage in continual dialogue with relevant groups, while providing accountability, quality, effectiveness and efficiency (Jongbloed, Enders \& Salerno, 2008).

However, so far there has been limited empirical exploration of how students and employers influence quality of education and participate in decision-making bodies and processes related to internal quality assurance. Are they treated as definitive stakeholders, as promoted by the ESG? We will explore the participation and contribution of students and employers to internal governance regarding quality assurance and programme improvements. First we will study the representation of students and employers in governance bodies (councils and committees). Then, we explore their participation and contribution to curriculum development, programme improvement and other processes that influence quality of education. Through this, we will be able to identify the power, urgency and legitimacy of each stakeholder category in quality assurance.

\section{Students as Stakeholders in Quality Assurance}

\subsection{Representation}

In the 28 higher education institutions, students are represented in various governing bodies related to internal quality assurance. Except in the UK, such representation is stipulated in national regulatory frameworks or accreditation requirements. Students as internal stakeholders are represented at all levels of the institutions, from the overall representative body such as the university senate or board, trickling down to faculty boards, examination committees and programme committees, academic ethics committees (e.g. Latvian cases) or 
disciplinary commissions (Slovak cases). Although in the Netherlands, students occupy half of the seats in the central democratic body of the institution and form the majority of votes with external stakeholders, in the other six countries students usually make up around 20 to 30 per cent of representative bodies. In Central and Eastern European countries students have been included in decision-making bodies since the changes of the 1990s. As noted in the Polish case studies, 1989 inaugurated a counter-movement against external political influence in the institutions. Yet overall we observe a tendency to include students in governing bodies and advisory committees related to internal quality assurance. Although most of this representation follows national regulations, some additional representation based on institutional rules has been also observed (e.g. in Latvia and Slovakia). Further, in the UK policy makers increasingly perceived students as legitimate stakeholders who should participate in evaluation processes, e.g. students are members of external review committees (as expected in the ESG). Further, national student surveys in the UK and the Netherlands have boosted legitimacy of the student voice in quality matters. Finally, student representation seems to be least 'used' in Portugal and the Czech Republic, as certain bodies at the chair level or at the university board level do not include students.

This shows that students are now perceived as important for the legitimacy of quality assurance processes across all seven countries. In terms of the Mitchel et al. (1997) typology this means that students are at least latent stakeholders in the cases in this study.

\subsection{Influence on Study Programmes and Curriculum}

How strong is students' legitimacy and is it complemented with power and urgency? In Portugal there is an attitude to limit the influence of students on curriculum reforms or programme changes, as this is perceived to be the domain of academics. Similarly, in the UK and Czech cases the researchers remarked that students' input can be 'tokenistic' since despite formal representation, students do not actually affect significant changes in internal quality assurance procedures or study programmes. The student voice in course evaluations does not necessary come through, or at least they miss feedback about follow-up, although clear procedures for course evaluation via student surveys are in place. While the issue in the Czech Republic and Portugal is that students are not always represented in shop-floor level committees, in the UK decision-making regarding quality of programmes is rather centralized and in that country national student satisfaction scores are important as they signal rankings of particular programmes. Thus, in fact, students in the UK are powerful and provide a sense of urgency to administrators and teachers to improve programmes due to this national survey, which has been conducted annually since 2005. Results from the survey are used, along with other data, to calculate university positioning in league tables and are perceived by the universities participating in this study as key drivers of change in how universities communicate with their students. Similar observations were made regarding the impact of the national student survey in the Dutch cases; there student representation and feedback for course improvement at the shop-floor level as well as overall power seem even stronger than in the UK. These two systems show that university management can fuel the impact of 
stakeholder groups as they use the results of internal and external surveys not only for internal study programme improvement, but also for building legitimacy and prestige in the outside world. Thus in the UK and the Dutch cases students are definitive stakeholders (See Table 1).

Table 1. Students as stakeholders in the case studies of seven countries

\begin{tabular}{|c|c|c|c|}
\hline Country & Latent Stakeholders & Expectant Stakeholders & Definitive Stakeholders \\
\hline Latvia & & $\begin{array}{l}\text { Students (legitimacy and } \\
\text { power) }\end{array}$ & \\
\hline Netherlands & & & $\begin{array}{l}\text { Students (power, } \\
\text { urgency and legitimacy) }\end{array}$ \\
\hline Poland & & $\begin{array}{l}\text { Students (power and } \\
\text { legitimacy) }\end{array}$ & \\
\hline Slovakia & & $\begin{array}{l}\text { Students (power and } \\
\text { legitimacy) }\end{array}$ & \\
\hline Czech Republic & Students (legitimacy) & & \\
\hline Portugal & Students (legitimacy) & & \\
\hline UK & & & $\begin{array}{l}\text { Students (legitimacy, } \\
\text { urgency and power) }\end{array}$ \\
\hline
\end{tabular}

Active student participation is observed in Poland and Latvia. Students seem to have wide and significant impact on revision of study programmes; they are involved in evaluations and in revisions of programmes' learning outcomes. Although the amount of influence varies per department and discipline, in all higher education institutions in these countries students are involved in self-evaluations of study programmes at various levels. Students fill out surveys through student unions besides the surveys conducted by the institution's educational office. In Latvian cases we saw examples of students initiating proposals for particular courses or training methods. Their comments were taken into account for course improvement and for upgrading learning resources. University administration used results of course evaluations to discuss with teachers about progress. In the Slovak cases, students were invited to negotiate with the faculty board about changes in study programmes. New curricula (including profile of graduates, learning outcomes, study plans, description of study subjects, criteria for acquisition of credits, etc.) were negotiated in the faculty academic senate, where students control at least one third of seats. Student survey results pointed to areas of improvement of courses and fed into departmental discussions of quality. It seems that students in these countries have power vested in them by the institutional management and their teachers. Thus we can characterise them as expectant stakeholders.

In sum, while in some countries like Portugal students are latent stakeholders as they fulfil the legitimacy criterion only, in the UK and the Netherlands students are on the other side of 
the spectrum, having gained power thanks to university management and to national student surveys.

\section{Employers as Stakeholders in Quality Assurance}

\subsection{Representation}

The representation of employers in the governance of higher education institutions is defined by national regulatory frameworks and by institutional ordinances. In the UK, the Quality Code of the national Quality Assurance Agency has guided the inclusion of external stakeholders into UK institutions.

In some countries (e.g. the UK, the Netherlands, Slovakia and the Czech Republic), external stakeholders are included in university courts or boards of trustees. For example, the Slovak higher education law requires boards of trustees to contain "personalities of public life including representatives of business sector, local and regional municipalities, regional governmental bodies who are responsible for education, finances, economy and social affairs in the region" (SK report, 2012). In the UK, the university courts, with their lay members, carry overall responsibility; yet responsibility of education is devolved to the university senate or council or its sub-committees. As in the Czech Republic, these latter bodies tend to be dominated by academics, although in some cases studied these bodies seek to enhance the range of views on issues of quality by creating an employability committee which contains employers from the local industry and which reports to the university court (UK report, 2012).

In some countries academic boards have strong powers concerning appointment of top institutional management, or reviewing the accounts and strategic direction of the institutions, as in the Netherlands. In others they largely have an advisory function, as in the Czech Republic. Similar boards exist in Latvia and Portugal, but there they are solely advisory and are regulated by the higher education institutions themselves. In Latvia, employers' participation is mainly organized through their participation in faculty-level boards of councillors and in examination committees. In Portugal these boards have been strengthened slightly with the introduction of more formal evaluations. The expectation of larger accountability towards society is vested in the inclusion of employers in each university's general council as external members, especially representatives of industry (PT report, 2012).

In Poland and the Czech Republic decision-making bodies consist solely of academics and students. External stakeholders are explicitly excluded, due to historical reasons of asserting institutional autonomy of the higher education institutions. However, as in the Slovak and Czech cases, national regulation prescribes participation of employers in examination commissions, scientific boards and boards of trustees, while in the Polish case employers closely linked with the study process and curriculum design, depending on specific profiles of various faculties. In Poland, according to the 2011 law on higher education, institutions must obtain external stakeholders' opinions on programme development. Further requirements are set for programmes with practical orientation; they should employ practitioners from the field 
as lecturers (PL report, 2012). Besides, employers are represented in the Employers' Council, in sector commissions at the faculty level and in the career office.

In the countries where external stakeholders participate in the governance of the institutions, employers are not always specified. It is then largely understood that external members may include academics from other higher education institutions, alumni, or prominent figures from the business or public spheres. (And sometimes they combine different criteria in the same person.) As shown in the UK and the Czech Republic, employers' organizations can be important in setting standards for learning outcomes and through participating in examination boards or in programme evaluations.

The representation of employers in the governance varies between different types of institutions in some countries. In the Netherlands, for example, universities of applied sciences are explicitly expected, because of their specific profile, to include employers and members of professions (including alumni) in programme committees and in the overall direction of the institution. While at universities this demand is less pronounced, as seen from programme accreditation rules. Moreover, institutions with specific orientation, for example technological universities (taken from the Czech example), are more likely to have industry representatives on scientific boards. Similar tendencies related to the character of the institutions are noted in Latvia, the Netherlands and the UK.

Further, not only the specific profile of an institution, but also its location can influence its including employers in quality assurance. One case study from Latvia showed a regional university actively seeking representatives of major employers from the region in its decisionmaking structures, as it aimed to serve regional labour market needs.

In most countries in the study, an important impetus for inclusion of employers in revision of programmes comes from programme accreditation rules. In some countries including employers is a requirement, in others an implicit suggestion. For example, in Latvia, the accreditation mechanism suggests that various groups of stakeholders should be involved in evaluation of the quality of the academic process, such as students, alumni, or employers. It is normally understood that those stakeholders should be surveyed regularly, to be accounted for in annual revisions of courses and in self-evaluations of study programmes (LV report, 2012). Given that the law in Latvia is not prescriptive in this regard, the accreditation expectations are important for inclusion of employers in institutional programme reviews.

In sum, we observe diverse approaches towards formal representation of employers in the governance of quality in the case studies across the seven countries. While a set of countries' national regulations see employers as legitimate stakeholders participating in the strategic development of the institutions, others let institutions decide how these stakeholders should contribute to the programme development and employability of graduates rather than strategic directions of the institutions. In these instances accreditation rules guide the representation, and stakeholders can gain urgency and power depending on the managerial preferences of the institutions. 


\subsection{Impact on Curriculum and Programme Design}

Irrespective of regulations, all case studies showed that employers are included in institutional processes related to quality assurance in the sense that they are consulted in curriculum design on an ad-hoc basis. Besides, representatives from companies teach at universities in applied disciplines, supervise student theses as well as accommodate student internships. These traditional exchanges are usually based on personal contacts of academics and are more prevalent in disciplines close to application, such as business and engineering. The informal exchange between academics involved in programme development and professionals from the field sometimes leads to collective decisions (as showed in Polish, UK, Dutch and Latvian examples) regarding changes of programme content or teaching methods (for instance, including internships).

The country studies showed that if formal presence of employers is ensured in various boards, their contribution and dedication is not always witnessed. For example, in the cases in Portugal, interviews revealed that only part of interviewees perceived stakeholder participation as effective. Others did not see it as contributing significantly to the governance of quality in the institution even though in some cases the representation was mandatory by law (PT report, 2012). The sceptics seemed to hold a conservative academic view that externals do not know enough about their institution or that stakeholders are often absent in discussions, which points to little real contribution, that is, neither urgency nor power (see Table 2). Similar views were expressed in UK cases, as 'lack of understanding' of institutional arrangements by external stakeholders (UK report, 2012).

Stakeholders in most countries are engaged at multiple institutional levels. In the Polish case employers seemed to have power and create urgency mainly at the faculty level as well as through personal contacts. Faculties have signed a range of agreements with a variety of firms as to increase employability of their graduates. Employers participated formally in programme committees and contributed to programme accreditation; informally they held power in practically-oriented programmes, as accreditation requires teachers from the working field. The requirement of internships is also codified. In some cases (postgraduate studies, internships) employers' opinion is a prerequisite for further action. In this way the consulting party has actual power over decisions.

Thus in the Polish cases, exchanges between employers and academics seem to be part of institutional practice, which has been codified only later into institutional representation and procedures. Employers seem to be strong expectant stakeholders in the Polish cases although their legitimacy is not derived from national regulation. Employers as expectant stakeholders can also be found in Slovakia, although their power is questionable. They are legitimate and expected to contribute to the governance of quality and they exhibit a sense of urgency. 
Leisyte, Westerheijden, Epping, Faber \& De Weert

Table 2. Employers as stakeholders in the case studies of seven countries

\begin{tabular}{|c|c|c|c|}
\hline Country & Latent Stakeholders & Expectant Stakeholders & Definitive Stakeholders \\
\hline Latvia & & & $\begin{array}{l}\text { Employers (power, } \\
\text { urgency and legitimacy) }\end{array}$ \\
\hline Netherlands & & $\begin{array}{l}\text { Employers (legitimacy } \\
\text { and power) }\end{array}$ & \\
\hline Poland & & $\begin{array}{l}\text { Employers (power and } \\
\text { urgency) }\end{array}$ & \\
\hline Slovakia & Employers (legitimacy) & & \\
\hline Czech Republic & Employers (legitimacy) & & \\
\hline Portugal & Employers (legitimacy) & & \\
\hline UK & & $\begin{array}{l}\text { Employers (legitimacy } \\
\text { and urgency) }\end{array}$ & \\
\hline
\end{tabular}

Some cases, e.g. institutions in Portugal and in the Czech Republic, seemed to hold a protective stance against employers as stakeholders. Most discussions and decisions on programme content were largely among academic staff, with some input from students. The influence of employers may transpire only through their involvement in setting national accreditation requirements for study programmes. Further, in the Portuguese case, formal representation of stakeholders in governance bodies was perceived as neither contributing to the development of programmes' curricula and requirements, nor to the development of quality assurance (PT report, 2012). In the Czech Republic only anecdotal evidence was found concerning involvement of employers in curriculum development, beyond their involvement in programme accreditation. Student internships are becoming increasingly common and they may influence some application-oriented programmes, such as engineering. Employers, if they are also teaching at a particular institution, may have informal authority to change the curriculum or exam requirements in discussion with academics. Another possible channel for employers' influence in the Czech case are final state examinations and theses defences, as also in other countries. Similarly, in Slovak cases the linkages between programme development and criteria-setting and employers functioned through student internships. Employers' views were taken into consideration, though mostly informally, as their positions were not codified in any way in procedures, requirements or regulations at the institutional, faculty or programme levels. The representation in various governance committees seemed not to have significant impact on core quality processes in the institution. Compared with other countries, employers in the studied Slovak institutions did not possess power or exhibit urgency. They were rather weak latent stakeholders. Thus, in these three countries, employers did not exhibit urgency and did not possess power to influence the governance of quality, although they had legitimacy postulated by national regulations and accreditation requirements. Accordingly, they are latent stakeholders (see Table 2). 
Multi-level engagement of employers was also evident in the UK case studies. The role of accreditation procedures and requirements was large in influencing the composition of curriculum review committees and in the prevalence of consultation with employers in applied disciplines, especially in regulated professions. There, the influence of professional standards was very strong. As noted in the UK report (2012), "subject groupings that receive professional accreditation, institutional and/or local policies determine the nature and scope of collaboration with professional bodies to define and develop curricula, including learning outcomes, assessment requirements and methodologies and skills development". In addition, as in many other countries, employers' views were taken on board through their role as external examiners and as external members in subject review panels during programme evaluations.

Finally, the Latvian case studies showed that in that country the formal authority vested in employers according to national regulations was indeed translated into institutional regulations. The faculty governing boards were composed of $50 \%$ employers and were directly responsible for academic issues. Through these boards, employers regularly influenced changes in the teaching and learning process (LV report, 2012). Besides, the institutionalized committees on quality, which are responsible for evaluation of new study programmes, also included employers as members. University regulations allocated a broad range of activities to employers. For example, "a by-law on councils of study programmes defines involvement of representatives of employers and highly qualified specialists as experts. There is an internal regulation on involvement of students, employers and alumni in preparation of self-evaluation reports on study programmes." Further, student internships and practical experience needed for the qualifications of teaching staff in applied fields were regulated by the institution (LV report, 2012). In fact, employers were included at all levels formally, besides informal contacts. It seems that the Latvian institutions and academics took the employability agenda seriously, in tandem with the whole set of national regulations, requirements of professional bodies and national accreditation. Thus, employers were included in the "development of study programmes, initial assessment of programmes, filling in the questionnaires for survey of employers, recruitment of high-class professionals for delivery of training, places and contents of graduation works, supervisors for graduation works and practical placements" (LV report, 2012). In the Mitchel et al. (1997) typology, employers in the Latvian case studies exhibit power and urgency besides legitimacy, i.e. they are definitive stakeholders.

\section{Discussion}

As we noted in the first section, the ESG have strongly emphasized the representation and impact of stakeholders on study programme development and governance of quality in the higher education institutions. The view of the stakeholders held in the ESG is that of definitive stakeholders who are fully engaged as legitimate participants and who hold urgency and power in decision-making processes around quality of education.

In this chapter we studied students and employers as stakeholders in 28 higher education institutions across seven countries. The findings reveal that the importance of stakeholders 
varies across the countries and across the types of stakeholders. Further, it has been observed that differences also exist within the systems across different types of institutions, faculties and disciplinary fields. This finding is in line with the observation of Ursin et al. (2008) that the role of stakeholders in quality assurance is highly context and discipline dependent. Yet on the whole we may conclude that students are represented widely in all higher education institutions in our study; these internal stakeholders hold a place second only to teaching staff. In the UK and in the Netherlands, students are definitive stakeholders, having legitimacy and power as well as urgency. In two other countries, the Czech Republic and Portugal, students are only latent stakeholders, having been given legitimacy by national regulation in line with the ESG.

The situation regarding employers is more diverse within the countries and depends on the applied character of study programmes, where linking with the profession or employers seems to be taken more serious among the actors in the higher education institutions, as Biglan (1973a, b) already posited. The power and urgency ascribed to stakeholders in such programmes and faculties seems decidedly higher than in pure sciences.

From our case studies, it appears that only in Latvia employers have reached the status of definitive stakeholders, while in three countries (again the Czech Republic and Portugal, but also Slovakia), they are no more than latent stakeholders.

Summing up, there is not a single country where both students and employers have definitive stakeholder status. The expectations implicit in the ESG are not fulfilled. The two countries where both students and employers are only latent stakeholders show the limits of what the ESG and the Bologna Process can achieve without active, self-motivated engagement from actors within higher education institutions. The mediating role of the institutional managers when it comes to giving (or not) power and urgency to various stakeholder categories appears to be crucial.

A few hints in our underlying national reports point to the conceptually obvious consideration that stakeholder categories are not homogeneous. Quite explicitly, the UK report mentioned that student representatives are mostly young, full-time students and do not include mature, part-time, international or disabled students. Similarly, in the Dutch report it was pointed out that employer representatives seem to hail from large companies rather than from small and medium enterprises (this would apply less to professionally organized fields, where the SME model often is predominant). Additionally, in several places it was mentioned that employer representatives were often recruited through alumni networks-on the one hand showing the usefulness of alumni networks for the benefit of quality of education, but on the other hand showing that there may be selection and self-selection biases among employer representatives, and that 'tunnel vision' or 'group think' are (distant?) risks (Janis, 1972). These hints furthermore could be connected to findings from collective action theory, i.e. that the organizational capacity of interest groups determines largely which points of view get represented in decision-making processes (Olson, 1971; Kingdon, 1984). 


\section{Acknowledgement}

Research undertaken in a project funded by the European Commission, entitled 'Identifying barriers in promoting the European Standards and Guidelines for Quality Assurance at institutional level', reference 511491-LLP-1-2010-1-CZ-KA1-KA1SCR, www.ibar-llp.eu. We acknowledge the contribution of Frauke Logermann for conceptual discussions.

\section{References}

Amaral, A. \& Magalhaes (2002). Governing Higher Education: National Perspectives on Institutional Governance. The emergent role of external stakeholders in European higher education governance. Springer Netherlands.

Biglan, A.(1973a). Relationships Between Subject Matter Characteristics And The Structure And Output Of University Departments. Journal of Applied Psychology, 57(3), 204-213.

Biglan, A. (1973b). The Characteristics Of Subject Matter In Different Academic Areas. Journal of Applied Psychology, 57(3), 195-203.

Deem, R. (1998). 'New managerialism' and higher education: The management of performances and cultures in universities in the United Kingdom. International Studies in Sociology of Education, 8(1), 47-70.

Douglas, J., Mc Clelland, R. \& Davies J. (1993). The development of a conceptual model of student satisfaction with their experience in higher education. Quality Assurance in Education, 16(1), 19-35.

Exworthy, M. \& Halford, S. (1999). Professionals and the new managerialism in the public sector. Buckingham: Open University Press.

Freeman, R. E. (1984). Strategic management: A stakeholder approach. Boston: Pitman.

Freeman E. \& McVea, J. (2001).A Stakeholder Approach to Strategic Management. Darden Business School Working Paper No. 01-02. Retrieved from http://papers.ssrn.com/sol3/papers.cfm? abstract_id=263511

Gumport, P.J. (2000). Academic restructuring: Organizational change and institutional imperatives. Higher Education, 39(1), 67-91.

Hill, F. (1995). Managing service quality in higher education: the role of the student as primary consumer. Quality Assurance in Education, 3(3), 10-21.

Janis, I.L. (1972). Victims of Groupthink: Boston: Houghton Mifflin.

Jongbloed, B., Enders, J. \& Salerno, C. (2008). Higher education and its communities: Interconnections, interdependencies and a research agenda. Higher Education, 56, 303-324.

Kingdon, J.W. (1984). Agendas, Alternatives, and Public Policies: Boston/Toronto.

Leisyte, L. and Dee, J. (2012) Changing Academic Practices and Identities in Europe and the US. Critical Perspectives. In Smart J.C. and Paulsen M.B.. Higher Education: Handbook of Theory and Research. Dordrecht: Springer.

Logermann, F. (2013) The ESG and their impact on students as stakeholders at European higher education institutions. A comparative study of Germany and the Netherlands. MSc thesis. University of Twente/University of Münster.

McDowell, L. \& Sambell, K. (1999). Fitness for Purpose in the Assessment of Learning: students as stakeholders. Quality in Higher Education, Volume 5, Issue, DOI: 10.1080/1353832990050202

Mitchel, R. K., Agle, B.R., Wood, D. J. (1997) Toward a theory of stakeholder identification and salience: defining the principle of who and what really counts. Academy of Management Review. Volume 27, pp. 853866.

Neave, G. (2002) On stakeholders, Cheshire Cats and Seers: Changing visions of the University. Enschede: University of Twente.

Olson, M. (1971). The Logic of Collective Action (2nd ed.). Cambridge, MA.

Savage, G. Nix, T. H., Whitehead, J. \& Blair, D. (1991). Strategies for assessing and managing organizational stakeholders. Academy of Management Executive.

Winter, R. (2009) Academic manager or managed academic? Academic identity schisms in higher education. Journal of Higher Education Policy and Management, 31(2), 121-131. 